\title{
STUDY AND CATALOGUING OF INDIGENOUS VERNACULAR ARCHITECTURE IN WESTERN PANAMA
}

\author{
M.A. Hervás Herrera ${ }^{1, *}$, J. González Quiel ${ }^{1}$ \\ ${ }^{1}$ SENACYT (Secretaría Nacional de Ciencia, Tecnología e Innovación), Panama - mangelhervas@yahoo.es; \\ jonathangonzalezquiel@gmail.com
}

Commission II - WG II/8

KEY WORDS: Panama, Vernacular Architecture, Indigenous Communities, Ngäbe, Buglé, Naso, Bribri

\begin{abstract}
:
The results of a research project on the vernacular architecture of indigenous communities in western Panama are presented. The field of study focuses on the indigenous territories of the Ngäbe, Buglé, Naso and Bribri ethnic groups, close to the border with Costa Rica. All of them belong to a well-defined geographical area and are linked by close historical, social and cultural ties. The constructions studied are based on the use of plant materials from their immediate surroundings, have enormous geographical, historical and ethnological value, and reflect the distinct lifestyles of the people who built and used them. Fully adapted to their natural environment and embracing high levels of environmental efficiency and sustainability, these constructions are nevertheless little known, little valued outside their region (and even within it), and are in serious danger of disappearing due to the introduction of new building materials. This paper presents the results of the current research project which emphasizes the morphology, structure, materials, construction techniques, typology and function of the buildings under study; and presents the working processes related to their construction.
\end{abstract}

\section{INTRODUCTION}

At the western end of the Republic of Panama, near the border with Costa Rica, live four indigenous groups (Ngäbe, Buglé, Naso and Bribri) who maintain a large part of their traditional lifestyles, especially in terms of architecture. The traditional constructions of these communities are based mainly on the use of plant materials from the immediate surroundings. They have enormous cultural, environmental and aesthetic value, and reflect very precisely the way of live, work and subsistence economy of the people who build and use them today.

Fully adapted to their natural surroundings and engineered with high levels of environmental efficiency and sustainability, these constructions have considerable importance to the identity of these peoples. As an expression of these societies and as a reflection of their adaptation to the environment, their significance is considerable. In fact, it is the indigenous people themselves who attach the greatest importance to the identity and environmental values of their traditional architecture. But this heritage is little known and scarcely valued outside the indigenous sphere and is particularly vulnerable to the conditions that compromise its conservation, especially in regards to globalization with the introduction of new building materials.

Indigenous knowledge of the traditional architecture of these communities can provide valuable data for the interpretation of the material remains of the Panamanian past, and serve as an aid to the interpretation of certain structures identified in archaeological sites in the country.

This is the case of the site of El Caño, an elite cemetery radiocarbon dated to the 8 th to 11 th centuries $\mathrm{AD}$, where the latest archaeological excavations have brought to light a large number of post holes in the ceremonial area, corresponding to missing wooden buildings, and whose interpretation is made difficult by the absence of scientific studies of nearby ethnographic parallels (Hervás, 2018).

Thus, it is of considerable interest to attempt the scientific study of this architecture, not only with the aim of safeguarding its unquestionable documentary value for the history of the country and its ways of life, but also, and above all, to lay the foundations for its adequate appreciation and consequent protection for the enjoyment of present and future generations. To this end, the National Secretariat for Science, Technology and Innovation of the Government of the Republic of Panama (SENACYT) is funding a research project entitled "Traditional architecture of the indigenous communities of western Panama", which began in early 2019 and is scheduled to end in December 2020. The project is managed by the Foundation for the Integral Community Development and Conservation of Panama's Ecosystems (FUNDICCEP). The work is being carried out by a multidisciplinary team of researchers made up of archaeologists, geographers, architects, botanists and anthropologists.

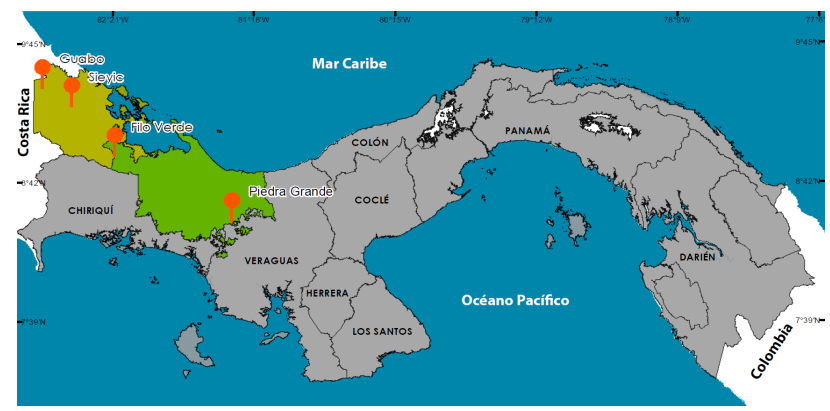

Figure 1. Map of location of the comunidades (I. Cárdenas).

* Corresponding author 
The selected study area is located in western Panama, within the Ngäbe-Buglé region and the province of Bocas del Toro. Specifically, in the communities of: Piedra Grande (Buglé territory, Agua Salud corregimiento, Nurum district, Ngabe Buglé Comarca); Filo Verde (Ngäbe territory, Tu Gway corregimiento, Jirondai district, Ngabe Buglé Comarca) Guabo de Yorkin and Dacle (Bribri territory, Las Delicias corregimiento, Changuinola district, Bocas del Toro province); and Sieiyic, Sieikin and San San Dru Di (Naso territory, Teribe corregimiento, Changuinola district, Bocas del Toro province) (igure 1). They form a coherent region of study because they belong to a well-defined geographical area with close historical, social and cultural links.

The research in progress is aimed at understanding the morphology, structure, materials, construction techniques, typology and function of the buildings produced with traditional techniques by the selected indigenous communities. The aim is to investigate the procedures involved in the construction of this architecture (mechanisms for obtaining, transporting and installing raw materials, systems for hiring personnel or for collaboration with the community, the hierarchy and degree of specialization of the personnel involved in the construction work, financing, costs, ownership, administrative procedure, etc.), and to contribute to their conservation and preservation on the basis of the appropriate social appraisal of these buildings and the traditional knowledge from which they derive.

\section{METHODOLOGY}

As a theoretical background, the research draws on the numerous international cultural heritage documents that highlight the values of traditional architecture, among which can be cited the following: Recommendation on the Safeguarding of Traditional Culture and Folklore (Mexico, 1989), Nara Document on Authenticity (Nara, Japan, 1994), Interamerican Symposium on Authenticity in the Conservation and Management of the Cultural Heritage of the Americas (San Antonio, Texas, USA, 1996) and Charter on the Built Vernacular Heritage (Mexico, 1999). All of which include vernacular architecture among the fundamental forms of expression of traditional culture, urge the documentation of it from primary sources to contribute to its conservation, highlight the importance of artisan traditions in relation to authenticity, and define built vernacular heritage as a direct response to the functional, social and environmental conditioning factors of the community, and as the product of traditional building systems, crafts and techniques.

This research project is creating a catalogue of the most representative buildings of traditional architecture of the selected indigenous communities, consisting of a database with data files on each, and providing the corresponding photographic and planimetric archives. This is accompanied by a publishable study that allows the geographical and historical contextualisation of the set of buildings studied, the morphotypological and functional classification of them, the assessment of their state of conservation and the corrective measures to be applied, and the identification of the peculiarities of the traditional architecture of each of the communities. To this end, four records are being handled simultaneously:

- A descriptive record based on a computerized inventory card model characterized by its versatility and structure, and by the capacity to contain graphic information;
- A photographic record based on a sequential approach to the building, and consisting of images taken at three different working scales or levels of detail: environment scale (views of the context of the building in the landscape and in relation to adjacent constructions); building scale (views of the different elevations of the building, both exterior and interior); and detail scale (shots of specific elements and construction details);

- A planimetric record based on sketches of the floor plan, section and elevation of the buildings studied, completed by obtaining three-dimensional digital models of the most representative examples of each of the typologies identified;

- Oral surveys carried out in the field with people previously selected for their knowledge of the building construction process, in which first-hand information is requested on aspects that are essential for understanding traditional architecture, such as the origin of the raw materials, the methods of obtaining them and the mechanisms for acquiring them, the reason for choosing certain materials for the construction of certain parts of the building, the processes of implementation, the function of specific rooms or elements of each building.

The buildings are being studied in their geographical and anthropological context, and the links between function, form and structural solutions are being investigated. Answers are being sought to the main questions (who, how, why, what for) raised by the various aspects of the construction process (materials, construction techniques, formal and structural solutions, functionality, efficiency, symbolic value, etc). It also assesses the state of conservation of the buildings studied, the risks they face, and the possible solutions to be adopted at different levels (regulatory, educational, dissemination...).

\section{THE AREA OF STUDY}

The research focuses on the indigenous territories of the four ethnic groups present at the west end of the country: Bribri and Naso in the province of Bocas del Toro, and Ngäbe and Buglé within their own region. These are peoples of pre-Hispanic origin, with Chibcha linguistic roots. These four ethnic groups belong to a well-defined geographical area, and have close historical, social and cultural links with each other, but also have very marked cultural characteristics of their own. Furthermore, they inhabit two very different physical environments (tropical rainforest and savannah in mountain areas), which makes for an interesting area of study in which to observe regional variability, and to assess the degree of influence of the physical and cultural environment on the different variants offered by the architectural manifestations of each group.

The physical environment is a determining factor in the definition of the traditional architecture of these groups, especially the climate, because it imposes conditions of temperature, sunshine and humidity that directly condition the habitability of the spaces (Díaz, 2018). In addition, it is the physical environment that provides the raw materials for construction, which in this case are almost exclusively of plant origin, and as is known, vegetation is strongly conditioned by climate. In the communities studied, moreover, the possibilities of transporting raw materials are particularly limited, because the tropical rainforest combined with the mountain landscape of Panama's Central Mountain Range means that many of these communities are not accessible by vehicle, but only on foot or on the backs of beasts of burden. 
The Ngäbe, Naso and Bribri communities included in the study are located in a tropical rainforest, where it rains almost all year round $^{1}$, there are high average temperatures ${ }^{2}$, and high levels of environmental humidity, which makes it necessary to raise the buildings to avoid the humidity of the land, to have permeable enclosures that allow the circulation of air to eliminate humidity by convection, and very dense and steeply sloping plant cover that acts as a thermal regulator of the interior spaces against the sun, and which resists the heavy downpours in the area. The physical environment provides a wide variety of palms, shrubs, vines and woods to be used in construction.

The Buglé communities, on the other hand, occupy an area of savannah in the mountains, with a tropical climate, but with variable rainfall throughout the year ${ }^{3}$, night temperatures lower than those of the rainforest ${ }^{4}$, high exposure to the winds, and a thin vegetation cover. There is less moisture in the soil, and it is necessary to protect against strong winds, so perimeter walls impermeable to draughts are preferred. Here the availability of plant materials is more limited, especially in terms of variety and size.

With regard to the cultural environment, the four indigenous groups in the study area appear to have their origins in populations of historical Chibcha roots established in the area since pre-Columbian times (Fonseca, Cooke, 1994. Marín, 2004). With some 154000 registered members, the Ngäbe people constitute the most important indigenous group within the study area, and the largest in Panama. Together with the Buglé, they have their own extensive region between the provinces of Bocas del Toro, Chiriquí and Veraguas, where they also have a significant presence. The social organization of the Ngäbe and the Buglé is based on a close relationship between land use and kinship, and the villages or comunidades of these ethnic groups are composed of family nuclei related and linked to each other by working relationships, which provides each community with internal strength. The Bribri occupy an extensive territory on both sides of the border between Panama and Costa Rica, so they have legal status as a cross-border group, although the Panamanian Bribri people are confined to a well-defined area along the banks of the Yorkin and Sixaola rivers, in the district of Changuinola in the province of Bocas del Toro. In this same district are settled the Naso, who constitute a minority group concentrated in a small area on the banks of the Teribe and San San rivers. Their cultural traditions are close to that of the Bribri, as they are closely related to the Talamancas of Costa Rica. They received strong influence from the Misquitos throughout the 18th and 19th centuries (Davis, 2010).

\footnotetext{
${ }^{1}$ Average monthly rainfall of between 197 and $289 \mathrm{~mm}$ in January, and between 242 and $322 \mathrm{~mm}$ in October (depending on the community) Data referring to the year 2019. Between December and February, abundant rainfall is recorded due to the incursions of the northern hemisphere's frontal systems towards tropical latitudes. In the rest of the year, rainfall is associated with tropical atmospheric systems moving over the Caribbean Basin, sea breezes and diurnal warming of the land surface. Source: ETESA Hidrometeorología Panama

(https://www.hidromet.com.pa/index.php).

${ }^{2}$ Average monthly temperature between 23 and $24.5^{\circ} \mathrm{C}$ in January, and between 23 and $24.9^{\circ} \mathrm{C}$ in October (depending on the community). Data referring to the year 2019. Source: ETESA Hidrometeorología Panama (https://www.hidromet.com.pa/index.php).

${ }^{3}$ Average monthly rainfall of $68,6 \mathrm{~mm}$ in January and $557,5 \mathrm{~mm}$ in October. Data referring to the year 2019. Source: ETESA Hidrometeorología Panama (https://www.hidromet.com.pa/index.php). ${ }^{4}$ Average monthly temperature of $26^{\circ} \mathrm{C}$ in January and $25,7^{\circ} \mathrm{C}$ in October. Data referring to the year 2019. Source: ETESA Hidrometeorología Panama (https://www.hidromet.com.pa/index.php).
}

\section{TRADITIONAL INDIGENOUS CONSTRUCTION IN PANAMA}

\subsection{The structure of the inhabited area}

The close historical, social and cultural links between these four ethnic groups has created a significant number of parallels and similarities in their respective ways of living and building. The population is distributed in small, widely dispersed, inhabited areas called comunidades, often close to large rivers, and almost always located in areas that are difficult to access. The majority of these nuclei lack any form of urban infrastructure. In areas of tropical forest, the Ngäbe, Naso and Bribri dwellings simply occupy a clearing in the forest, created by the inhabitants when they cultivate the surrounding land. These are separated from neighbouring dwellings by distances that sometimes exceed one hundred metres, by stretches of virgin tropical forest (Figure 2). The same is true of the Buglé communities in mountain savannah areas, which are made up of scattered dwellings in a sparsely vegetated environment. In this cultural area there is tendency to centralise the inhabited centre, probably because of the absence of a dense vegetation, the opposite of the tropical forest. The result is more centralization of households, although again without urbanization. Nor is there any service infrastructure such as sewage treatment, drinking water or electrical distribution networks. Each family has a toilet connected to a cesspit, located within the family's property, but several tens of meters away from the living area.

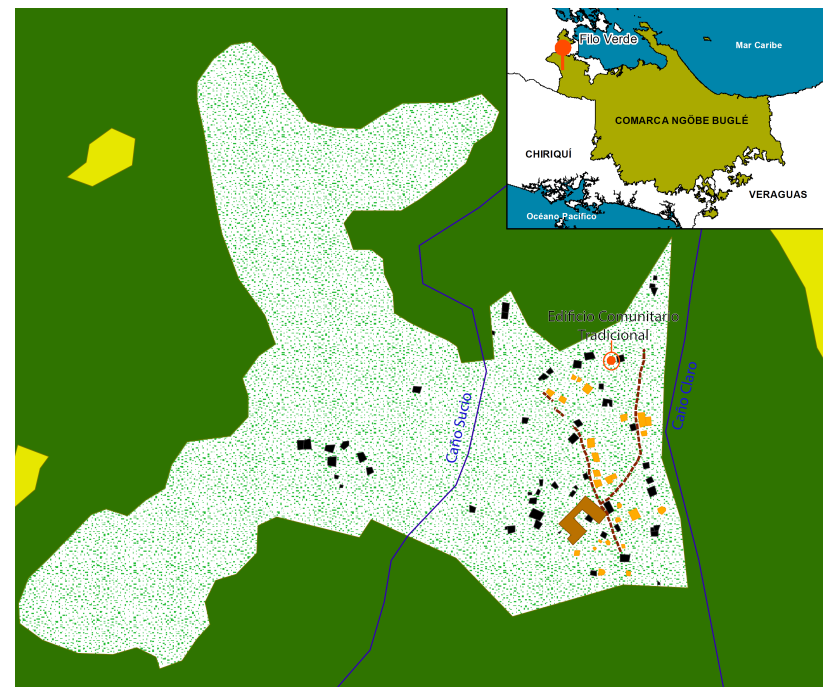

Figure 2. Map of Filo Verde, Ngäbe area (I. Cárdenas).

In many of these villages, part of the core habitation area is organized around a large communal square that serves as a field for playing football or holding festivities or public events, around which communal buildings are distributed, such as the school, the church, the meeting room for holding community assemblies, the communal justice room, or the doctor's office. This pattern is not part of indigenous cultural traditions but rather, is the result of a policy promoted by the Panamanian State during the government of General Omar Torrijos (1968-1981) to provide the communities with a homogeneous structure.

On the other hand, these nuclei are endowed with a margin of internal mobility, since, under certain circumstances -such as the exhaustion of the farming land in the immediate surroundings- families can dismantle their houses and reassemble them a few hundred meters away, maintaining themselves within the same community. 


\subsection{Raw materials for construction. Procurement and transport}

It is an almost exclusively plant-based architecture, constructed of woody and herbaceous plants, using species from the immediate environment (Figure 3).

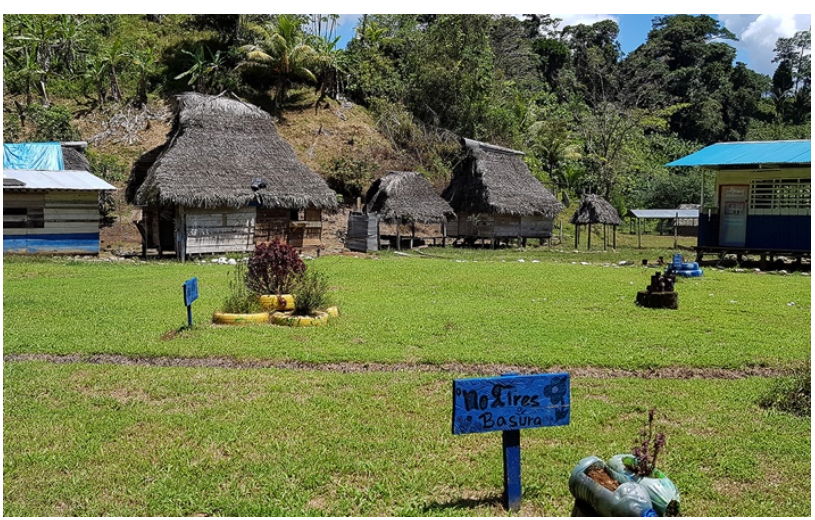

Figure 3. Primary school in Los Santos, Ngäbe territory.

The structural elements are made from tree trunks or branches of various species, chosen from those available in the immediate surroundings according to their physical properties and the structural requirements of each piece. Thus, in the ethnic groups established in areas of tropical forest, the posts destined to support the weight of the whole structure with a base embedded directly in the soil, and in direct contact with high indexes of capillary humidity, are manufactured from dense and hard woods species, such as the palo criollo (Minquartia guianensis), the arraiján (Eugenia ligustrina) or the mangrove (Rizophora mangle L. and Pelliciera rizophorae). For wooden beams, knee braces, joists, rafters, and other parts, lighter and more flexible woods are preferred, but with good mechanical properties, such as laurel (Cordial alliadora). Perimeter walls and floor coverings are made of hawthorn cedar (Bombacopsis quinata), which is a light wood with inferior structural behaviour to laurel. For the auxiliary elements such as railings, parapets, partitions, etc., trunks and barks of different types of palm -chonta (Iriartea deltoidea), jira (Socratea exorrhiza), pifá (Bactris gasipaes)- are used, which are soft woods that are easy to work (Ocampo, 1994). Traditionally, vines (long, thin and resistant stems that hang from certain species of tropical trees) have been used to tie the elements together, although in recent times industrially produced nylon thread is frequently used. Sometimes the roof structure is assembled from pieces of bamboo, a very light, flexible and extremely resistant material, but which is more often reserved for the construction of fences.

The architectural element that has the greatest material variety among the ethnic groups under study is the plant material used for the cover of the roof. While the Bribri roof their buildings with the leaves of an herbaceous plant called suita (Asterogyne martiana), the Naso do so with palanquilla leaves (Geonoma congesta), the Ngäbe with conga palm leaves (Welfia georgii), and the Buglé with the so-called paja hueso (Trachypogon plumosus), omnipresent in the surrounding savannah (Ocampo, 1994).

The current research project has also documented the extraction processes of these raw materials. In the rainforest, the extraction points are located in the vicinity of the inhabited centers, or next to the banks of the rivers, which serve as transport routes (Figure 4). The cutting of logs for beams or boards is usually done at the extraction point itself, since they are usually located in places inaccessible to vehicles. Traditionally, cutting was done with axes, wedges and mallets, and with long two-handed saws. Today, it is done with chainsaws, which have been widely used in the area for these tasks since the 1990s. Wood cutting is the only truly specialized work done in this type of construction. The reminder activities in the construction process are carried out by the families themselves.

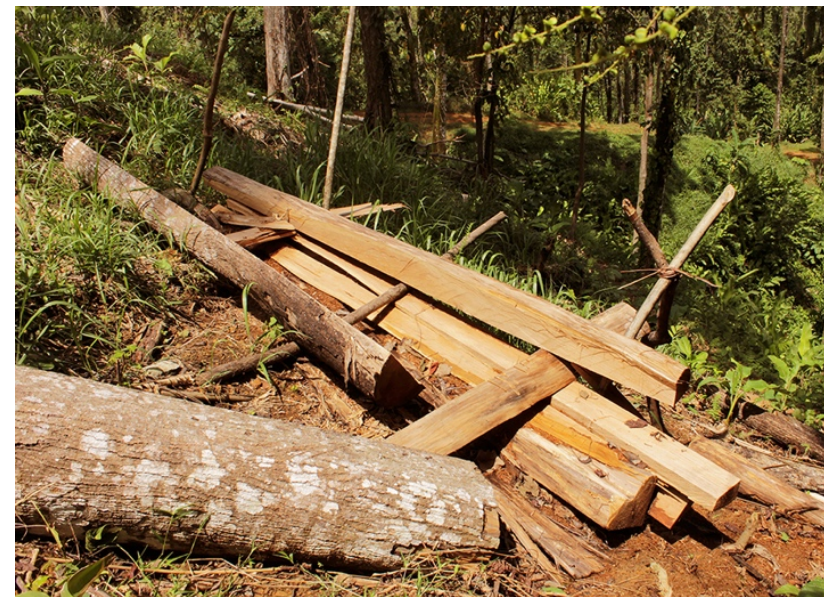

Figure 4. Extraction point near San San river, Naso territory.

The transport of beams, boards, herbaceous plants or palm leaves from the extraction points to the construction site is almost always done on foot, sometimes with the help of horses, or at most, taking advantage of the river currents and the natural buoyancy of the wood (Figure 5), as most communities are inaccessible to motor vehicles.

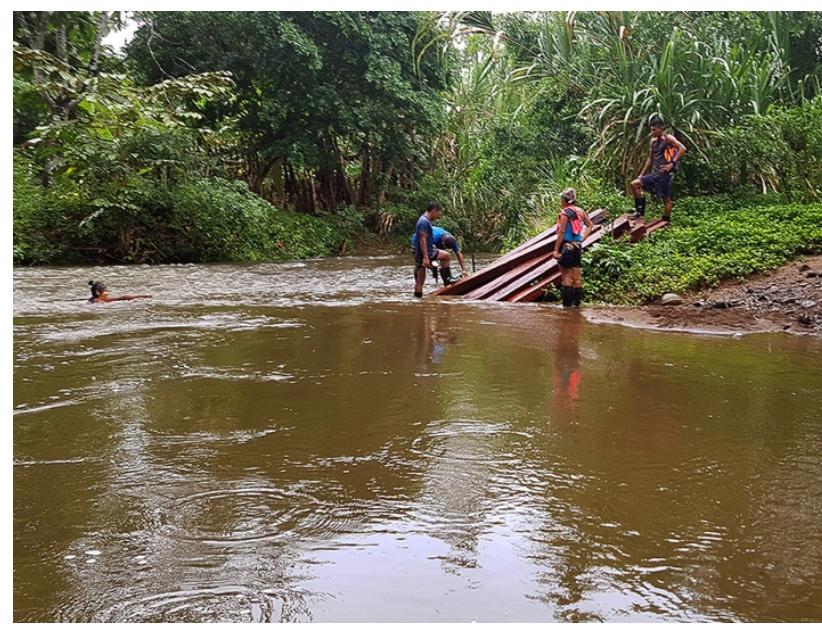

Figure 5. Transporting wood along a river in Naso área.

\subsection{Typology of buildings}

The oldest documented type of building in the study area is a circular construction with a conical shape, in which the roof structure rests directly on the ground without vertical walls (Figure 6). This first model is closely related to the indigenous worldview, to the world of ancestral beliefs of the indigenous groups studied. Between the Ngäbe and the Buglé, the round house, made of a single piece, a single fireplace and a single cupboard, is linked to the concept of a common house, the first 
ever built, and is closely linked to nature (Quintero, 2017). Among the Bribri, this first conical model, called the Ú-Shure, has its origin in the Cosmic House, and was the image of the house built by Sibö, a metaphor for the world inhabited by human beings, a microcosm reflecting the macrocosm (Guevara, s/d. González, González, 1989).

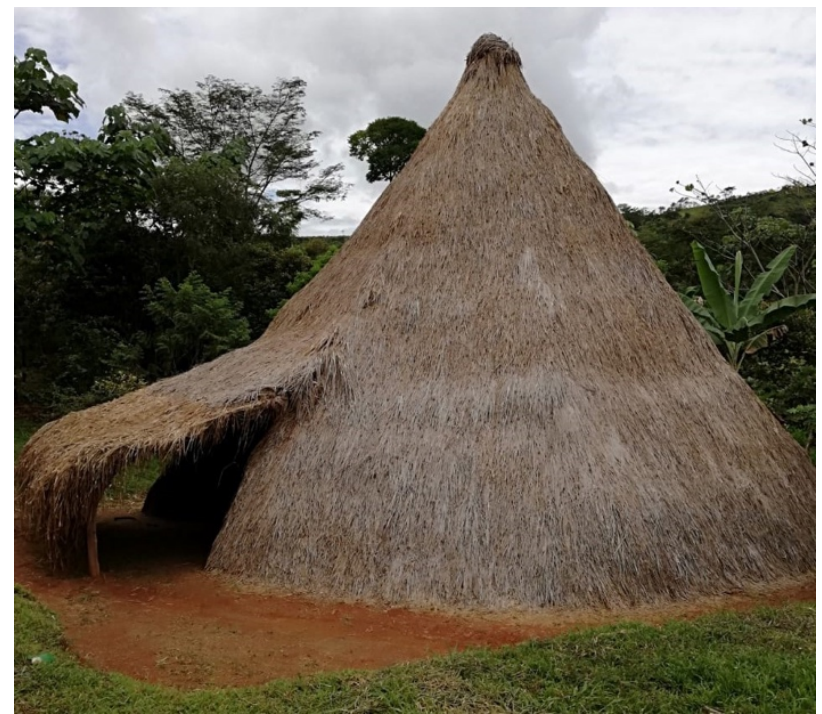

Figure 6. Bribri Cosmic House in Cabagra (Costa Rica).

Over time, this initial model evolved towards the separation of the conical structure of the roof from the terrain, through the interposition of a vertical perimeter wall formed by the juxtaposition of boards or branches arranged vertically, on which the base of the conical roof rested, maintaining the circular floor plan (Figure 7).

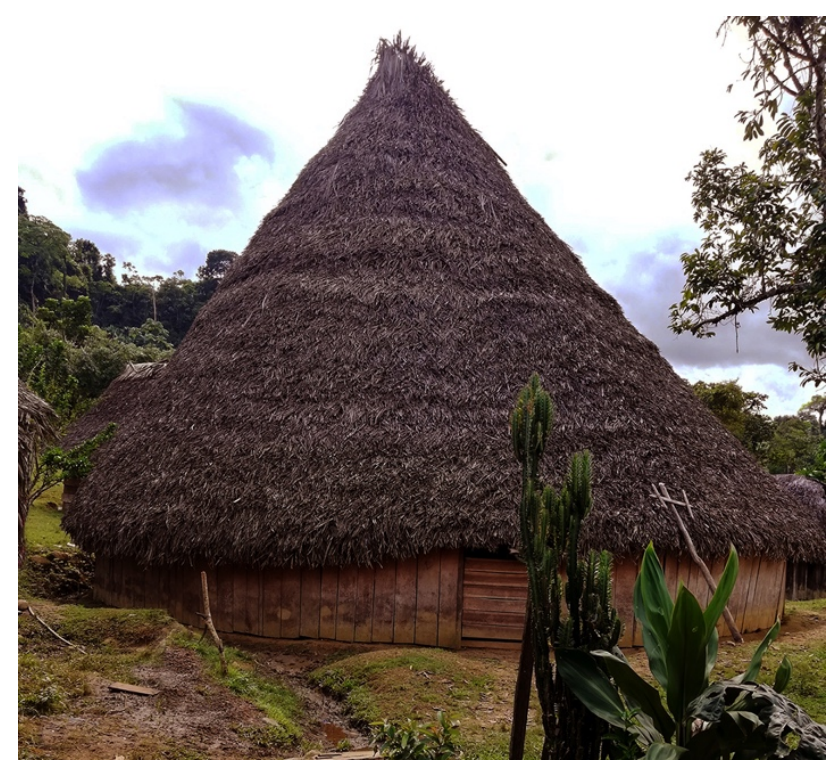

Figure 7. Traditional house in Coclecito, Ngäbe territory.

Progressively, the conical roofs stopped ending in a point and begin to do it with a small horizontal ridge tile (Figure 8), without losing its cone-shaped design. The progressive elongation of this incipient ridge tile gave rise to the appearance of oval or rectangular constructions with short curved sides, directly on the ground, and finished off by gable roofs with a longitudinal ridge tile, which the Bribri call Orowe.

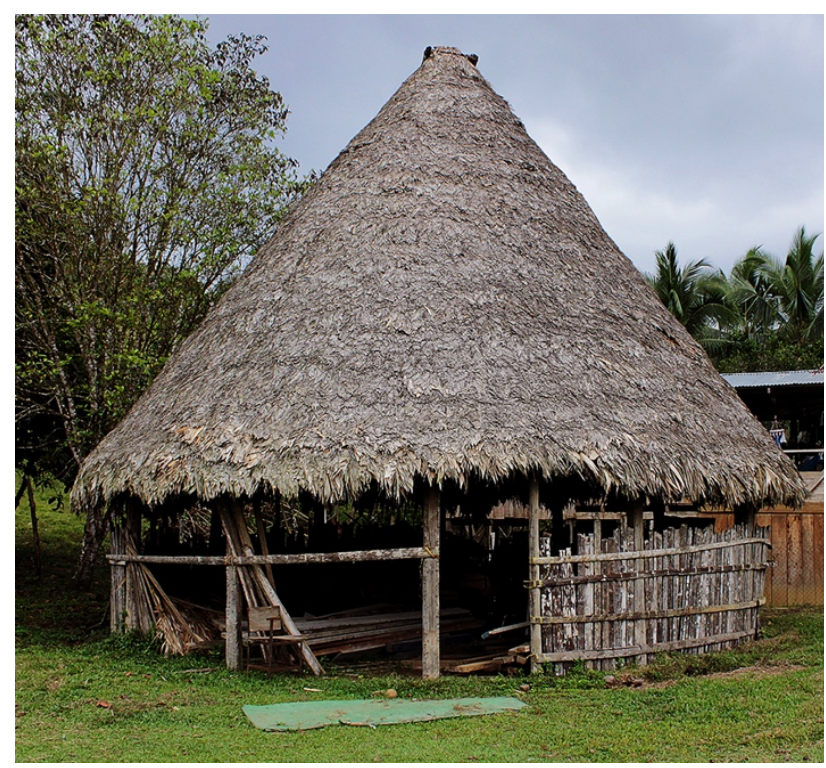

Figure 8. Primary school building in Sieikin, Naso territory.

The establishment of large foreign fruit and banana companies in the area during the first decades of the 20th century introduced important external influences on traditional lifestyles, which in the field of domestic architecture was manifested in the appearance of houses raised on poles or rightangled wooden feet, in the form of palafittes, with hipped roofs and floor plans made up of several adjoining buildings that form a single residence, often in the wake of an expansion process of the initial nucleus (Figure 9). One of these buildings is usually used exclusively for the kitchen, and it often retains the traditional plant-based roof and the circular or polygonal floor plan on six or more sides, as opposed to the modules for the bedroom, which have adopted a quadrangular or rectangular floor plan, replacing the traditional plant roof with four slopes with a single or double-slope zinc roof. These dwellings are known in the Bribri area as Tambo.

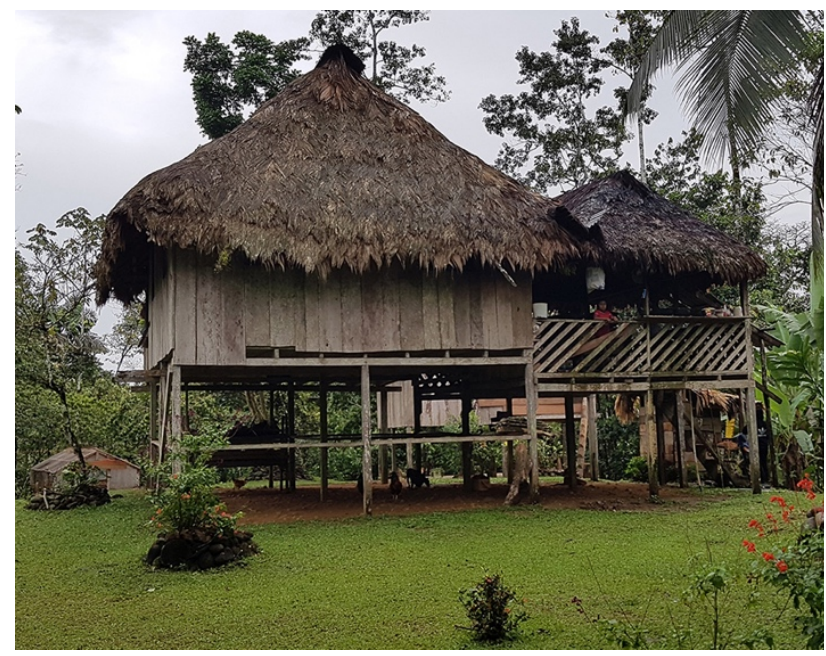

Figure 9. Tambo house in Sieikin, Naso territory.

\subsection{Constructive variants by ethnic groups}

Apart from the common features described above, there are some significant differences between the constructions of the ethnic groups studied. These are primarily found in the design of the roof covering and in the raw materials used to make it. 
In Naso territory, hipped roofs with continuity between their skirts on both sides of the hip rafters are common (Figure 9). The roof structure is assembled on hip rafters and straps made on laurel, tied with vines or nylon thread. The skirts of the long sides of the roof are usually structurally reinforced by means of oblique braces arranged in the same plane as the skirt itself, which prevent the structure from folding lengthwise (Figure 10). The roof is made from palanquilla leaves, which are sewn by their petioles when still green, with vines or nylon thread, to a thin straight rod up to $3 \mathrm{~m}$ long (caña brava: Gynerium sagittatum), to form the esteras (mats), which have to be completely dried in the shade before being put in place. Bark from the chonta palm is used for railings and for some floors.

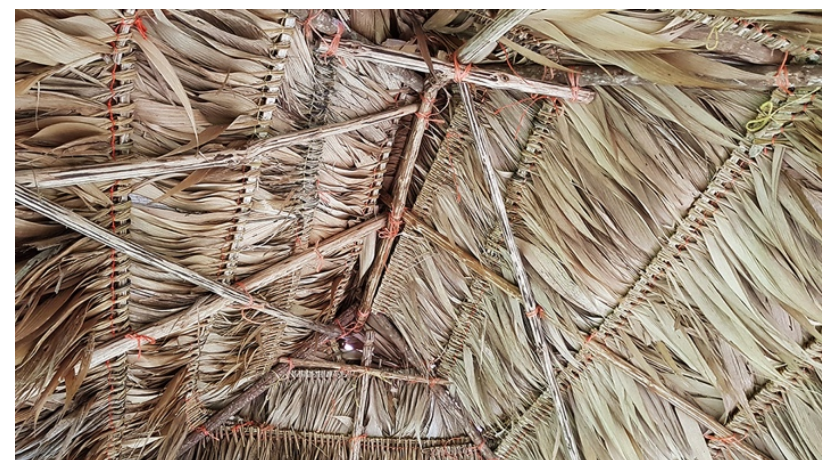

Figure 10. Oblique braces reinforcing the roof structure (Naso).

In Bribri territory, hipped roofs have the skirts of the long sides overlapping those of the short sides (Figure 11). At the upper end of both gables, next to the ridge tile of the short skirts, a triangular space is left unprotected to favour ventilation of the interior and thus guarantee the evacuation of smoke and humidity from the interior (Figure 12). The roof structure is assembled with laurel branches, and the cobijo (shelter) is made with suita leaves sewn to a long stick to form esteras, in the same way that the Naso do (Figure 13).

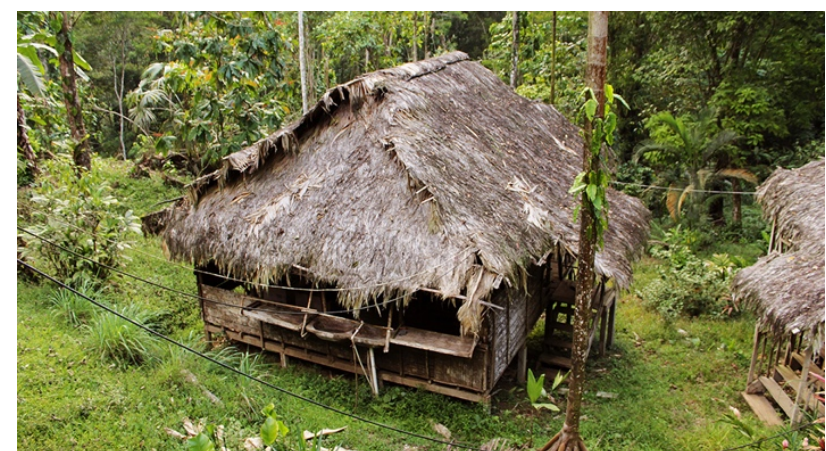

Figure 11. Alakölpa project, in Guabo de Yorkin (Bribri area).

In both Naso and Bribri territory, the esteras are attached to the roof structure with vines or nylon thread, with the rod in a horizontal position, and overlap each other from bottom to top, to prevent rainwater infiltration during the run-off phase. The smoke from the kitchen helps to waterproof the blankets and make them more resistant to rot and insects. The durability of a cobijo is between 10 and 30 years, and depends on four factors: the density of leaves on each estera, the density of esteras in the cobijo, the degree of smoking of the plant material that makes up the cobijo, and whether the leaves have been cut with the moon in four wane. As far as it is known, there is no scientific basis to explain the latter, but among the indigenous people it is a deeply held belief.

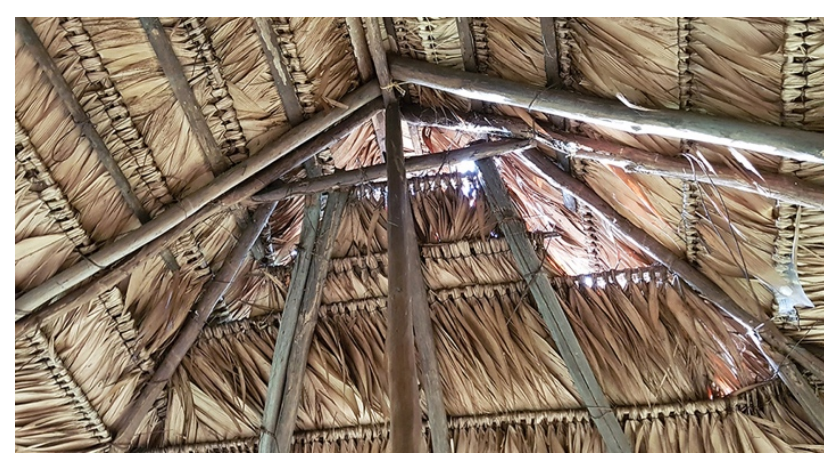

Figure 12. Free space at the upper end of the gable for ventilation, in a building in Guabo de Yorkin (Bribri area).

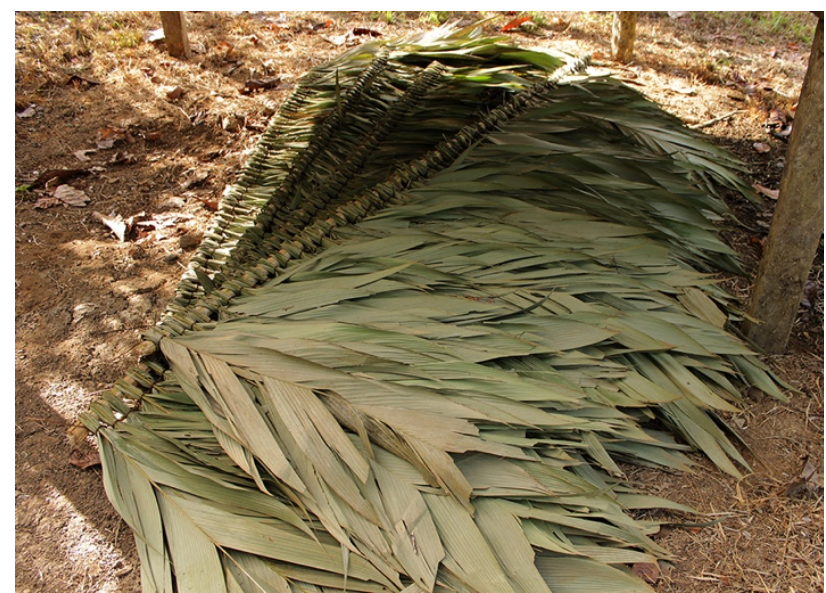

Figure 13. Esteras made with suita leaves, in Bribri area.

In Ngäbe territory it is also common to see the overlapping long skirts of the roof over the short skirts, as happens between the Bribri, although with very marked peculiarities, such as the fact that one of the two short skirts descends in its development until it reaches the base of the floor, leaving that side of the house without a vertical wall, precisely on the flank where the kitchen is located (Figure 14). The Ngäbe cobijos are made from palm leaves. Each leaf is cut longitudinally in two halves by the center of its main nerve, and after drying naturally, the halves are placed against each other, one with the leaflets downwards, and the other with the leaflets upwards.

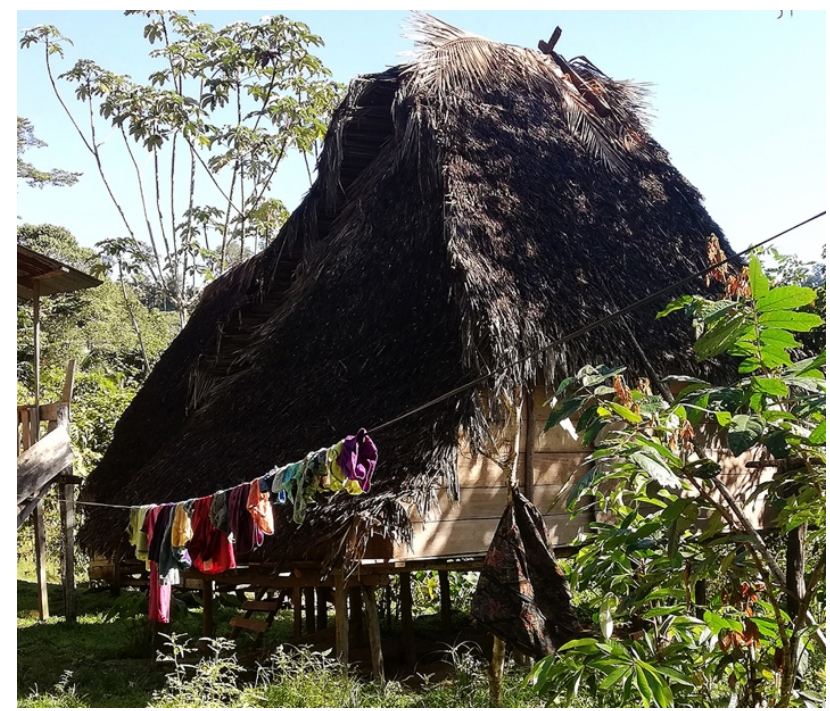

Figure 14. Ngäbe cobijo at Quebrada Pita. 


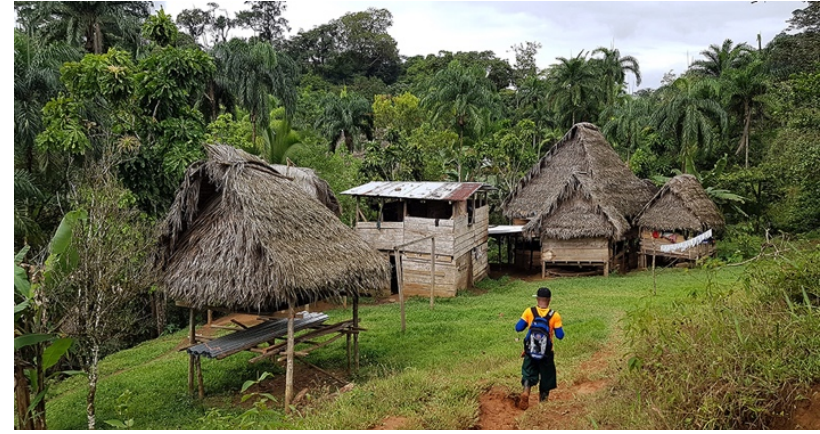

Figure 15. Comunidad de Los Santos, Ngäbe territory.

In the Buglé territory, located in a mountain savannah environment (Figure 16), the physical environment imposes environmental conditions that are substantially different from those of the tropical forest, which translates into significant differences in terms of the design of the buildings and the materials used for their construction. As a defense mechanism against strong winds, the dwellings are not made up of a single two-storey body, but of several small, single-height buildings, very close to one another, grouped together inside the family property, which is usually fenced around its perimeter. Each of these buildings normally consists of a single living space with its own well-defined function (Figures 17 and 18). In each family compound, buildings with a circular floor plan and conical roof alternate with those with a rectangular floor plan, many of which are already covered with corrugated zinc sheets.

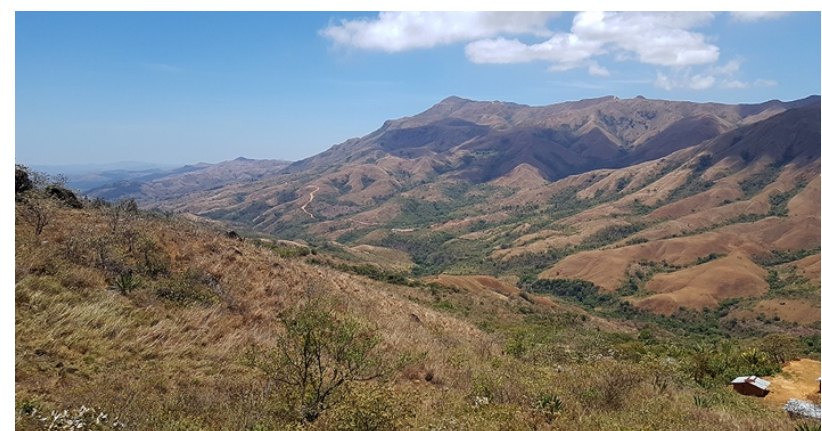

Figure 16. Savannah environment of Piedra Grande (Buglé).

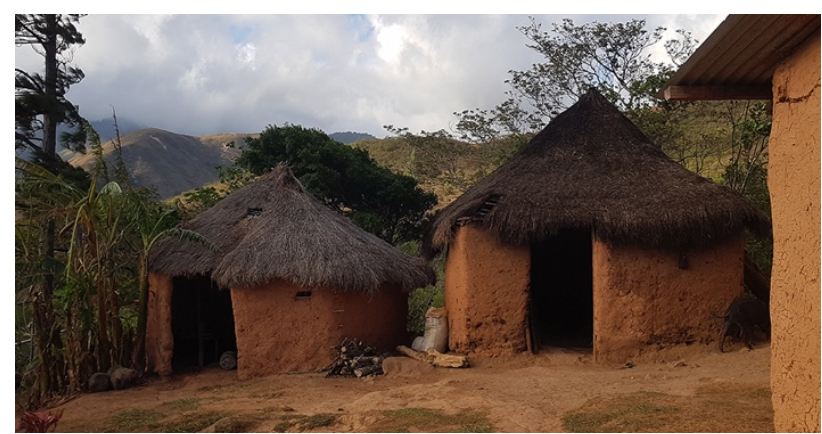

Figure 17. Buglé houses at Piedra Grande.

In both circular and rectangular buildings, the level of use of the interior of the house is the surface of the land itself, a solution that is favoured by the low levels of capillary humidity. The vertical perimeter wall at the base of the building is built from mud freshly applied on a previous frame made from twisted branches, thus isolating the interior space from the wind and from the drop in night-time temperatures, in an environment of low ambient humidity.

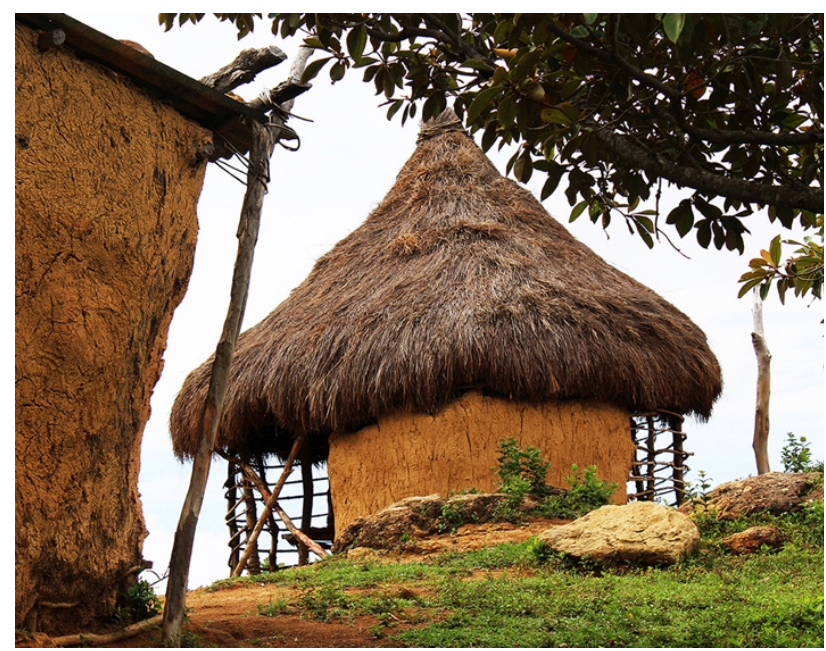

Figure 18. Buglé house at Batata.

In buildings with a circular floor plan, the conical roof rests on four vertical beams separated from the walls, inside the living space. Those with a quadrangular or rectangular floor plan are finished with hipped roofs. The roof structure is made with a light network of branches and poles because of the absence of larger plant species in the surrounding area (Figure 19). The cobijos are made with the so-called paja hueso (Trachypogon plumosus), which grows abundantly in the local meadows. The Buglé house is the result of indigenous cultural traditions that adapted to a savannah environment in a mountain area.

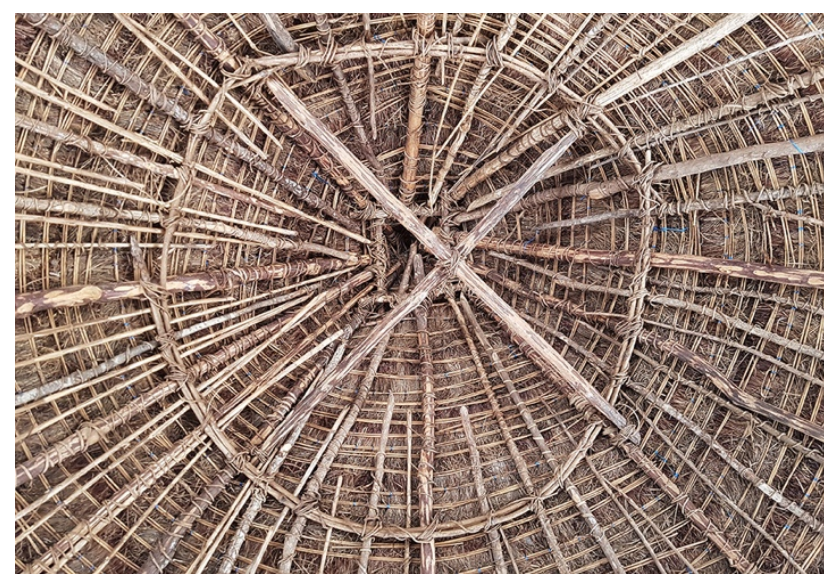

Figure 19. Roof structure of a Buglé building at El Peñón.

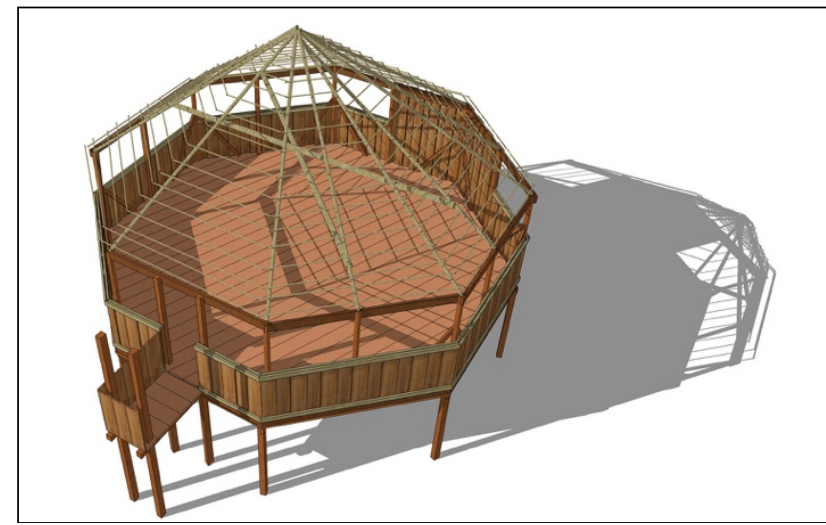

Figure 20. 3D drawing of House of Justice in Guabo de Yorkin. 


\section{CONCLUSIONS}

The research project described here aims to promote knowledge of the traditional architecture of Panama's indigenous communities as an essential first step towards the subsequent active protection of this heritage and for the future action programs aimed at guaranteeing its conservation, dissemination and promotion to society. It also aims to raise awareness among the communities themselves of the value of their vernacular architecture as an outstanding element of Panama's cultural heritage, and to show them that buildings constructed using traditional techniques have cultural, social and identity value. This awareness will undoubtedly be the most effective tool to guarantee the conservation of this heritage for future generations.

The buildings studied have an undoubted value as vernacular heritage, but they are perishable in the short term: on the one hand, because of their organic construction in a tropical environment, which makes them vulnerable to the action of humidity and xylophagous; and on the other hand, because the families themselves show a high degree of mobility, and often dismantle their homes in order to assemble them in a new location. None of the buildings studied so far are more than 30 years old, and many of them have been erected in the last decade, despite their ancestral appearance.

These circumstances lead to an observation on the protection of this type of heritage. Under such conditions it is not possible to protect the buildings themselves. The intangible heritage that generates them must be protected, that is to say, the ancestral knowledge, and the use of traditional materials, construction techniques and morpho-typology. The indigenous people themselves are concerned that this knowledge and oral tradition will be lost. Thus, the mechanisms of transmitting this knowledge must be preserved.

\section{ACKNOWLEDGEMENTS}

The advances in the knowledge of the traditional indigenous architecture of western Panama obtained in the course of this research project have been possible thanks to the collaboration of numerous people from different fields.

We would like to thank the Ngäbe, Buglé, Naso and Bribri peoples of Panama for having hosted the members of the research team on the many tours they made, and for having given us access to their homes and shown us their ways of life.

We thank the National Secretary of Science, Technology and Innovation of the Republic of Panama (SENACYT), and all those people who from this institution have managed the different facets of the project.

We also thank the Foundation for Integral Community Development and Ecosystem Conservation in Panama (FUNDICCEP), for having accepted to participate in the management of the project, for having trusted the members of the research team, and for the economic support provided during the first field trips.

Finally, we thank Herbert D. G. Maschner $\mathrm{PhD}$ for the academic proofreading.

\section{REFERENCES}

Davis, E., 2010. Diagnóstico de la Población Indígena de Panamá con base en los Censos de Población y Vivienda de 2010. Contraloría General de la República, Instituto Nacional de Estadística y Censo, Panamá.

Díaz Camacho, M. Á., 2018. Arquitectura y cambio climático. Arquia Foundation, Madrid.

Fonseca, Ó. M. y Cooke, R., 1994. El sur de América Central: contribución al estudio de la región histórica chibcha. Historia General de Centroamérica. Historia Antigua. San José, Costa Rica.

González Chaves, A. y González Vásquez, F, 1989. La Casa Cósmica Talamanqueña y sus simbolismos. Editorial de la University of Costa Rica, San José, Costa Rica.

Guevara Berger, M., s/d. Mitología y Cosmovisión en Talamanca: una interpretación dialéctica de la tradición oral indigena. Unpublished source.

Hervás Herrera, M. Á., 2018. Las estructuras funerarias de El Caño (Coclé, Panamá) entre los siglos VIII y X. Proceso constructivo y transformaciones postdeposicionales. Proceedings of the $56^{\circ}$ International Congress of Americanists (Salamanca, 16-20 july 2018), (2), 112-127.

Marín Araya, G., 2004. La población de Bocas del Toro y la Comarca Ngöbe-Buglé hasta inicios del siglo XIX. Anuario de Estudios Centroamericanos, 30 (1-2), 119-162.

Ocampo, R., 1994. Estudio etnobotánico de las palmas empleadas por los indígenas en Talamanca, Costa Rica. Revista Forestal Centroamericana, 7, 16-21.

Quintero Sánchez, B., 2017. La casa Ngäbe y Buglé. Ni Tä Nüne Ju Kwatibe Te. Vivimos en la misma casa. Postgraduate Thesis in Social Anthropology, University of Panama, Panama. 